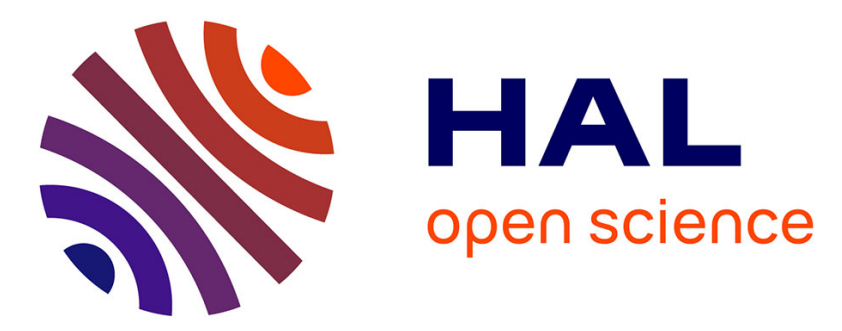

\title{
Dehydroalanine and lysinoalanine in thermolyzed casein do not promote colon cancer in the rat.
}

\author{
Denis E. Corpet, Sylviane Taché, Michael C Archer, W Robert Bruce
}

\section{To cite this version:}

Denis E. Corpet, Sylviane Taché, Michael C Archer, W Robert Bruce. Dehydroalanine and lysinoalanine in thermolyzed casein do not promote colon cancer in the rat.. Food and Chemical Toxicology, 2008, 46 (9), pp.3037-42. 10.1016/j.fct.2008.06.002 . hal-00334558

\section{HAL Id: hal-00334558 \\ https://hal.science/hal-00334558}

Submitted on 27 Oct 2008

HAL is a multi-disciplinary open access archive for the deposit and dissemination of scientific research documents, whether they are published or not. The documents may come from teaching and research institutions in France or abroad, or from public or private research centers.
L'archive ouverte pluridisciplinaire HAL, est destinée au dépôt et à la diffusion de documents scientifiques de niveau recherche, publiés ou non, émanant des établissements d'enseignement et de recherche français ou étrangers, des laboratoires publics ou privés. 


\title{
Dehydroalanine and Lysinoalanine in Thermolyzed Casein do not Promote Colon Cancer in the Rat.
}

\author{
Denis E. Corpet ${ }^{a}$, Sylviane Taché ${ }^{\mathrm{a}}$, Michael C. Archer ${ }^{\mathrm{b}}$, and W. Robert Bruce ${ }^{\mathrm{b}}$

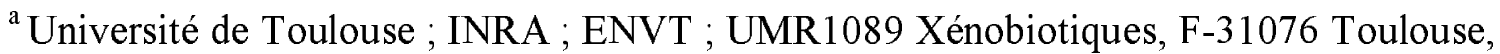 \\ France \\ ${ }^{\mathrm{b}}$ Department of Nutritional Sciences, Faculty of Medicine, University of Toronto, Toronto, \\ ON, Canada. \\ Corresponding author: \\ Denis E. Corpet, Ph.D., \\ UMR1089; INRA; ENVT \\ BP-87614, 23 ch. des Capelles, \\ 31076 Toulouse, France \\ E-mail: d.corpet@envt.fr \\ Tel: +33561 193982 \\ Fax: +33561491263 \\ Running title: No Promotion by DHA or LAL \\ Abbreviations: \\ ACF, aberrant crypt foci; AOM, azoxymethane; DHA, dehydroalanine; LAL, lysinoalanine.
}

\begin{abstract}
Thermolysis of proteins produces xenobiotic amino-acids such as the potentially toxic lysinoalanine, and the alkylating agent, dehydroalanine, which have been considered possible health hazards. We observed that thermolysed casein promoted aberrant crypt foci (ACF) and colon cancer growth in rats initiated with azoxymethane and speculated that promotion might be due to the formation of these compounds. To test this notion we first measured the concentration of the modified amino acids as a function of thermolysis time. The concentration of dehydroalanine in the casein paralleled the degree of promotion, that of lysinoalanine did not. We then tested diets containing foods with high levels of dehydroalanine (thermolysed sodiumcaseinate, cooked Swiss cheese) for their effect on ACF promotion. They decreased the number and/or size of ACF significantly, indicating that dehydroalanine did not promote, but protected rats against colon carcinogenesis. These results do not support the notion that lysinoalanine or dehydroalanine are a hazard with respect to colon carcinogenicity.
\end{abstract}

\section{Introduction.}

Cooking produces potentially toxic xenobiotics in foods. Best known, perhaps, are the carcinogenic heterocyclic amines formed when meat is cooked at high temperatures (Sugimura et al., 2004). Maillard reaction products and advanced glycation end products are produced in foods when proteins and carbohydrates are heated together. Also produced in vivo, they are involved in diabetic complications, cardiovascular disease, renal disorders and possibly cancer (Bachmeier et al., 2008; Vlassara et al., 2008). Protein subjected to much lower temperatures or to alkali treatment can also form compounds that have been of concern for over 30 years (Finley and Friedman, 1977). Thermolysis of casein, for instance, results in the dehydration of serine, 
with the formation of dehydroalanine (DHA) in the protein chain. DHA is an electrophile that could be toxic when consumed as it acts as an alkylating agent in vitro, and might, therefore, alkylate enzymes and DNA in vivo (Friedman, 1999). In food, DHA frequently alkylates lysine to yield the crosslinking amino acid lysinoalanine (LAL) (Cheftel et al., 1985). Foods containing LAL are widely consumed in infant formulas, baby foods, cereal products and cooked meats (Friedman, 1999). The concentration of LAL is currently lower in commercial foods than in the past, but low value in UHT milk increases up to $0.16 \mathrm{mg} / \mathrm{g}$ protein within a 60 day storage, and liquid infant formula may contain up to $0.5 \mathrm{mg} / \mathrm{g}$ protein (Cattaneo et al., 2008; D'Agostina et al., 2003). In contrast, levels in several home-cooked are particularly high. For instance, pan-fried egg white and grilled cheese contain more than $1 \mathrm{mg}$ LAL /g (Maga, 1984; Sternberg et al., 1975), and though LAL is not mutagenic, it is toxic to the kidneys of rats (De Groot et al., 1976; Pintauro et al., 1985; Struthers et al., 1977). LAL and DHA have never been evaluated for their possible carcinogenicity. Several other modified amino-acids have been detected in heated proteins, but LAL is, by far, the most abundant, except lanthionine in alkaline treated wool (Friedman, 1999).

Diet can play a major role in the development of many cancers including colorectal cancer. Dietary recommendations have been made for reducing cancer incidence (WCRF, 2007), but the specific determinants of risk have not yet been defined, and we do not know which dietary agents initiate or promote many cancers including colorectal cancer. The manner in which food is prepared could be as important as the nutrient composition of the diet. Indeed, we have shown previously that diet components that have been heated in a kitchen oven can markedly enhance colon carcinogenesis (Corpet et al., 1990). In particular, casein that has been thermolysed in a manner to simulate household cooking consistently promotes the growth of the putative preneoplastic aberrant crypt foci (ACF) and colon cancer (Corpet et al., 1990; Zhang et al., 1992). The mechanism responsible for this tumor promotion by cooked casein is not known, despite consistent efforts (Corpet and Cassand, 1995; Corpet and Chatelin-Pirot, 1997; Corpet et al., 1997a; Corpet et al., 1995). We speculated that promotion might be due to the formation of a toxic agent inside the protein chain: an agent released in the gut by the digestive enzymes, but not extracted from the intact protein chain. Among the xenobiotic amino-acids formed in heated casein, DHA is an alkylating agent (Friedman, 1999), and LAL is present in high concentration (Sternberg et al., 1975)

The hypothesis that DHA and LAL are the promoting molecules that explain the promoting activity of thermolysed casein was tested here in three in vivo experiments. One examined how the levels of LAL and DHA in casein thermolysed for various times compared with its promoting activity. A second compared the levels of LAL and DHA and promotion observed with sodium caseinate as used in experimental diets. A third evaluated the effect of these measures in grilled Swiss cheese. Promotion was assessed by scoring the growth of the putative preneoplastic aberrant crypt foci (ACF) (Bird, 1987; Corpet and Tache, 2002).

\section{Materials and Methods}

\subsection{Animals.}

For the kinetics study, performed in Toronto, five-week-old female F344 rats were obtained from Harlan Sprague-Dawley (Indianapolis, IN). Similar rats were obtained from Iffa-Credo (Arbresle, France) for all other studies, performed in Toulouse. Rats were acclimatized to the colony for one week, housed by pair in plastic cages on wood chips (Toronto) or in stainlesssteel wire drop-bottom cages (Toulouse), at $22^{\circ} \mathrm{C}$ with 12:12-hour light-dark cycle, and fed a laboratory chow (6\% fat, Teklad Premier Lab. Diets, Madison Wis., or UAR, Villemoisson, 
France) and water ad libitum. The rats were initiated with one i.p. injection of azoxymethane (AOM, Sigma, Mississauga, Canada, or St.Quentin, France) at a dose of $20 \mathrm{mg} / \mathrm{kg}$ in normal saline. They were randomly allocated to the appropriate control or experimental diets, as described below. These studies lasted $107 \mathrm{~d}$, starting with carcinogen injection, followed by a week on laboratory chow, then $100 \mathrm{~d}$ on experimental diets. The animals were weighed weekly, fecal samples were collected, and food and water intake was measured per cage in the middle and at the end of each study. Care was in accordance with the guidelines of the Canadian and the European Councils on Animal Care.

\subsection{Diets and studies design.}

The experimental diets were based on the standard AIN-76 diet (American, 1977), which was modified to contain $20 \%$ beef tallow and $3.5 \%$ corn oil, except as noted in the third study. Fat was added to the diet at the expense of carbohydrate and the diets differed only in their protein components as previously described (Corpet et al., 1990).

Kinetics study: Casein (vitamin free, ICN) was thermolysed for 1, 2, or $4 \mathrm{~h}$ as thin layer in a Pyrex pan in a domestic electric oven at $180^{\circ} \mathrm{C}$ (Corpet et al., 1990). The experimental diets then contained $12.5 \%$ untreated casein and $15 \%$ thermolysed casein $(\mathrm{w} / \mathrm{w})$. The control diets contained 27.5\% untreated casein. One week after AOM initiation, 78 rats were randomized to four dietary groups: 28 rats in a control group given the untreated casein-based diet, and 16, 17 and 17 rats in three experimental groups given diets with casein thermolysed for 1,2 or $4 \mathrm{~h}$. At the end of the $100 \mathrm{~d}$ feeding period, rats were sacrificed and colonic ACF scored.

Na-caseinate studies: Casein (ICN) and Na-caseinate (Sigma chemical) were thermolysed for $2 \mathrm{~h}$ at $180^{\circ} \mathrm{C}$. Rats were fed diets containing either casein or Na-caseinate, either unthermolyzed or thermolyzed, in a $2 \times 2$ design: experimental diets contained $20 \%$ thermolysed protein (casein or Na-caseinate) and 5\% untreated casein, while control diets contained $25 \%$ untreated protein (casein or Na-caseinate). To mimic the abrasiveness of thermolysed casein, two other diets were made by adding $10 \%$ carborundum $(\mathrm{SiC}$, particle size $0.5 \mathrm{~mm}$, Prolabo, Paris, France) to the raw and thermolysed Na-caseinate diets. One week after AOM initiation, 60 rats were randomized to six dietary groups of ten rats, and fed for $100 \mathrm{~d}$ the six diets described above and reported in Table 1.

Cheese study: Swiss cheese (Emmental, 45\% fat in dry matter, Prodif, Laval, France) was thermolyzed for $1.5 \mathrm{~h}$ in an oven set at $200^{\circ} \mathrm{C}$. Cheese temperature increased nearly linearly during $90 \mathrm{~min}$ from $115^{\circ} \mathrm{c}$ to $200^{\circ} \mathrm{C}$. At the end of the thermolysis, cheese color was medium golden brown, similar to what is seen on top of a grilled pizza. Control and experimental diets were made with the same amount of dry matter from cheese $(47.8 \%)$. The control diet was made with unthermolyzed cheese, while the experimental diet was made with thermolyzed cheese. One week after AOM initiation, 20 rats were randomized to two dietary groups of ten rats, and fed for $100 \mathrm{~d}$ the two diets described above and reported in Table 2 . Rats eating thermolyzed cheese diet had soft stools, and their body weight gain was approx. 66\% of controls' at day $30(\mathrm{p}<0.001)$. Experimental diet was thus changed at day 33 , to include $1 / 4$ of unthermolyzed cheese and $3 / 4$ of thermolyzed cheese in the cheese part, which normalized the stools and improved the weight gain.

\subsection{Assay of $A C F$.}

Aberrant crypts were scored as previously described (Bird, 1987; Corpet et al., 1990). Briefly, 100 days after initiating injections, rats were sacrificed by carbon dioxide asphyxiation. Colons were removed, cut lengthwise, fixed in formalin, and examined after staining with Methylene Blue by transmitted light from the mucosal surface at 40x magnification. The multiplicity of each focus referred to as "size" and measured as the number of crypts in the focus was recorded 
for each of the ACF observed in each of the animals. All colons from a single study were scored by a single blinded observer.

\subsection{Assay of LAL and DHA.}

2.4.1. LAL was analyzed by a method based on that described by Deng et al. (Deng et al., 1990). A $5 \mathrm{mg}$ protein sample was hydrolyzed in $5 \mathrm{ml} 6 \mathrm{~N} \mathrm{HCl}$ in a PICO-Tag hydrolysis jar (Millipore-corporation, 1984) for $22 \mathrm{~h}$ at $105^{\circ} \mathrm{C}$ under vacuum. The hydrolysate was adjusted to $\mathrm{pH} 9.0$ with $12 \mathrm{~N} \mathrm{NaOH}$. A $0.25 \mathrm{ml}$ sample of the hydrolysate together with $0.25 \mathrm{ml}$ borate buffer $(0.25 \mathrm{M} \mathrm{pH} 9.0)$ were reacted with $0.25 \mathrm{ml} 180 \mathrm{mM}$ dansylchloride at room temperature for $1.5 \mathrm{~h}$, the reaction products were loaded on to a C18 Sep-Pak cartridge and LAL was eluted with $20 \%$ acetonitrile in water. The eluate was analyzed by HPLC on a C18 Novapak column $(3.9 \times 300 \mathrm{~mm}$, particle size $4 \mu \mathrm{m})$ eluted with $33 \%$ acetonitrile in $0.01 \mathrm{M}$ phosphate buffer $(\mathrm{pH}$ 7.0). UV absorbance was monitored at $254 \mathrm{~nm}$. The amount of LAL in the protein samples was calculated based on the standard curve of authentic LAL. The detection limit was $50 \mathrm{ppm}$ with an overall recovery of $98 \%$.

2.4.2. DHA was measured according to Bartone (Bartone et al., 1991) by reaction with 2pyridilethyl mercaptan as originally used by Masri and Friedman (Masri and Friedman, 1982). A $1 \mathrm{mg}$ protein sample was suspended in $1.6 \mathrm{ml} 0.1 \mathrm{M}$ triethylamine (TEA) and $0.8 \mathrm{ml} 0.2 \mathrm{M}$ pyridylethyl mercaptan (Toronto Research Chemical, Toronto, Canada) in acetonitrile. The mixture was kept at $37^{\circ} \mathrm{C}$ for $16 \mathrm{~h}$ with occasional shaking and was then evaporated to dryness under vacuum. A portion of the dried sample was hydrolyzed as described above, and then dried again from a solution containing ethanol : water : TEA $(2: 2: 1)$. The dried sample was dissolved in $5 \%$ acetonitrile in phosphate buffer $(0.01 \mathrm{M}, \mathrm{pH} 6.8)$, loaded on C18 Sep-Pak, washed with water and then eluted with $6 \%$ acetonitrile in phosphate buffer. The eluate was analyzed by HPLC on a C18 Bondapak column $(7.8 \times 300 \mathrm{~mm}$, particle size $10 \mu \mathrm{m})$ eluted isocratically with the same eluent.

The product was confirmed as S-(2-pyridylethyl)-cysteine by $1 \mathrm{H}-\mathrm{NMR}$ and electrospray HPLC/MS. NMR spectra in $\mathrm{D}_{2} \mathrm{O}$ were obtained with the use of a Varian NMR $500 \mathrm{MHz}$ UnityPlus spectrometer (Palo Alto, CA). The proton NMR spectrum assignments and chemical structure are given in the Annex. Further purification of the material followed by a two dimensional COSY NMR experiment verified the proton-proton connectivities of the cysteine ${ }^{1} \mathrm{CH}$ resonance at $4.00 \mathrm{ppm}$ with the ${ }^{2} \mathrm{CH}$ methylene resonance at $3.12 \mathrm{ppm}$. The S-ethylene cysteine side chain spectrum was simulated using the above parameters as an $\mathrm{ABX}$ subspectrum for the cysteine portion with an M2XY subspectrum for the S-ethylene portion. The calculated spectrum duplicated the observed spectrum, in particular the methylene group attached to the sulfur appeared as a doublet of triplets due to the asymetric environment created by the neighboring optically active center of the cysteine. In the NMR spectrum of the starting material, 2-pyridylethyl mercaptan, both methylene groups appear as triplet resonances at 3.07 and 2.94 $\mathrm{ppm}$. The HPLC/MS spectrum was obtained following the isocratic elution of the C18 column described above with $8 \% \mathrm{CH}_{3} \mathrm{CN}$ in $\mathrm{H}_{2} \mathrm{O}, \mathrm{pH} 3.3$ followed by electrospray mass spectrometry (PE Sciex API-III, Thornhill, Canada). The spectrum yielded a molecular ion mass of 227.

2.4.3. DHA in thermolysed proteins and fecal samples of the second and third studies was measured using a protocol based on that of Kleyn and Klostermeyer (Kleyn and Klostermeyer, 1980), since DHA identification had been done in the first study. The protein was hydrolyzed to release amino acids, and DHA was transformed into pyruvic acid that was then assayed with a standard enzymatic procedure. A $100 \mathrm{mg}$ protein sample or $200 \mathrm{mg}$ fecal sample, were hydrolyzed in $4 \mathrm{ml} 3 \mathrm{~N} \mathrm{HCl}$ for $2 \mathrm{~h}$ at $100^{\circ} \mathrm{C}$ in a stoppered flask. Using methyl red as 
indicator, $\mathrm{pH}$ was brought to 6 with $2.05 \mathrm{ml} 5 \mathrm{~N} \mathrm{NaOH}$, then the volume was adjusted to $10 \mathrm{ml}$ with $\mathrm{H}_{2} \mathrm{O}$. After centrifugation at $700 \mathrm{~g}$ for $5 \mathrm{~min}, 0.2 \mathrm{ml}$ sample of the supernatant was assayed for pyruvic acid. The assay was done by the enzymatic method from Boehringer Manheim GMBH, Biochemica 1989 book (pp 116-118). Pyruvic acid was reduced to lactate by NADH with L-lactate-dehydrogenase. The decrease in NADH was determined by its absorbance at 340 $\mathrm{nm}$. Detection limit was $300 \mathrm{ppm}$ DHA. Day-to-day coefficient of variation was $15-20 \%$, and recovery of authentic N-CBZ-DHA $80 \%$.

\subsection{Statistical methods.}

Comparison between groups were made by ANOVA (several groups), by Student's t test (two groups), or by Fisher's exact test (tumor incidence data). Differences with bilateral $p$ values below 0.05 were considered significant.

\section{Results}

\subsection{Effect of thermolysis time on LAL, DHA and ACF promotion.}

To determine whether LAL and DHA could be responsible for colon cancer promotion, their levels in casein cooked for $0,1,2,3$ and $4 \mathrm{~h}$ were assessed. The concentration of LAL increased at 1 and $2 \mathrm{~h}$ (Fig. 1A) reaching a maximum concentration of $3000 \mathrm{ppm}$, but then decreased with further thermolysis. In contrast the concentration of DHA increased steadily with thermolysis time, and reached $7000 \mathrm{ppm}$ at $4 \mathrm{~h}$ (Fig. 1B). ACF size, however, increased monotonically with thermolysis time (Fig. 1C), suggesting that promotion is not related to the concentration of LAL but could be related to the concentration of DHA. The weight gain of the animals receiving diets containing thermolysed casein was less than that of the animals on the control diet: the final mean weight of rats given the diet with $15 \%$ casein thermolysed for $2 \mathrm{~h}$ was $215 \pm 3 \mathrm{~g}$, significantly less than control rats $(247 \pm 4 \mathrm{~g}, \mathrm{p}<0.01)$. The animals showed no signs of distress, and no other evidence of toxicity was detected during necropsy.

\subsection{Effect of thermolysed Na-caseinate, with a high DHA content, on ACF promotion}

3.2.1. To determine whether DHA promoted the growth of ACF, rats were fed diets containing either casein or Na-caseinate, either unthermolyzed or thermolyzed, in a $2 \times 2$ design. As shown on Table 1, thermolysis of either casein or Na-caseinate increased DHA content. Cooked casein and Na-caseinate contained more than $5000 \mathrm{ppm}$ DHA, and the DHA concentration in feces reflected the intake. The animals showed no signs of distress, and no evidence of toxicity was detected during necropsy, except a non significant reduction in body weight gain due to thermolysis (Table1). As previously shown (Corpet et al., 1990; Zhang et al., 1992), the feeding of cooked casein did not change the number of ACF per colon, but promoted the growth of ACF compared to raw casein-fed controls (a 34\% increase in ACF multiplicity, $\mathrm{p}<0.0001$ ). Tumor promotion was also evidenced by the finding of 6 macroscopic tumors in 5 rats fed cooked casein out of 10 , when no tumors were found in 10 controls $(p=0.03)$. In contrast, the feeding of cooked Na-caseinate did not promote the growth of ACF. Indeed, thermolysis of Na-caseinate led to a $57 \%$ decrease in the number of ACF $(p<0.002)$ and to a $27 \%$ decrease in ACF multiplicity $(p<0.0001)$. A replication of this French experiment in Canada yielded similar results.

\subsection{Effect of a diet containing DHA and abrasive particles on ACF promotion}


Microscopic examination showed that cooked casein particles had a mean size of $170 \mu \mathrm{m}$, but Na-caseinate particles were much smaller, i.e. $30 \mu \mathrm{m}$. The casein particles appeared like sharp pieces of broken glass, while Na-caseinate particles appeared less sharp. Since a previous study suggested that mucosal abrasion might be the cause of thermolyzed casein promotion (Corpet and Chatelin-Pirot, 1997), we tested the hypothesis that the promotion of ACF by cooked casein was due to the simultaneous effect of large abrasive particles and of DHA toxicity. Therefore, rats were fed a diet containing simultaneously $10 \%$ carborundum (sharp particles of $500 \mu \mathrm{m}$ ) and thermolyzed Na-caseinate, high in DHA. The diet containing carborundum and thermolysed caseinate significantly reduced body weight gain (Table 1), but no other sign of toxicity was observed. As can be seen in Table 1 (lower panel), carborundum had no effect on the growth of ACF as reported before (Corpet et al., 1997a). As observed above, the thermolyzed Na-caseinate decreased the ACF number and size compared to controls fed raw Na-caseinate ( $p$ values < 0.0001 ) and the addition of carborundum had no additional effect. These data thus do not support the hypothesis that cooked casein promotion is caused by a combination of mucosal abrasion and DHA

\subsection{Effect of grilled Swiss cheese, with a high DHA content, on ACF promotion.}

To test a diet high in DHA that is eaten by humans, rats were fed a diet containing $48 \%$ Swiss cheese, either unthermolyzed (controls), or $25 \%$ unthermolyzed plus $75 \%$ grilled ( $1 \mathrm{~h} 30$ in a $200^{\circ} \mathrm{C}$ oven). The thermolysis enhanced the DHA content of cheese from below the detection limit to more than $3000 \mathrm{ppm}$ DHA (Table 2). The diet containing $36 \%$ grilled cheese was toxic to the rats: Compared to control rats, rats given the grilled cheese ate less food (6.5 vs. $7.2 \mathrm{~g}$ ingested dry matter/day, $\mathrm{p}=0.02$ at day 90), had smaller body weight gain (164 vs $194 \mathrm{~g} / \mathrm{rat}$, $\mathrm{p}<0.0001$ ), excreted more acidic feces ( $\mathrm{pH} 6.8 \mathrm{vs} 8.1 \mathrm{p}<0.0001)$ and had enlarged ceca (4.2 vs. $2.4 \mathrm{~g}, \mathrm{p}<0.0001)$. Thermolysis of cheese did not promote, but strongly reduced the growth of $\mathrm{ACF}$ in rats. As shown on Table 2, the number of ACF/colon was not changed, but the number of crypts per ACF, and the number of large ACF was much decreased in rat fed grilled cheese. These data do not support the hypothesis that DHA in food promotes carcinogenesis.

\section{Discussion}

The results clearly show that DHA, and suggest that LAL, alkylating and cross-linking aminoacids that are produced during protein cooking, do not promote the growth of ACF and are thus not likely major causes of cancer promotion by thermolysed casein.

The evidence that LAL is not a major promoting agent is circumstantial: its concentration in thermolysed casein did not show the same time-course as ACF promotion (Fig1-A and C). In addition, Na-caseinate contains high levels of LAL (370-1300 $\mu \mathrm{g} / \mathrm{g})$ according to the literature (Friedman, 1999) and it did not promote ACF compared to LAL-free casein (Table 1). Similar decreases in LAL in overcooked protein have already been described, but the nature of the degradation products is not known (Friedman, 1999). DHA is not a major promoting agent since thermolysed Na-caseinate, which contained a high concentration of DHA, actually reduced the size and number of ACF in the colon of rats (Table 1). In addition, diets containing high levels of DHA either with abrasive carborundum particles $(500 \mu \mathrm{m})$ or in cooked cheese, protected rats against colon carcinogenesis (Tables 1 and 2). It is possible that smaller carborundum particles would have better mimicked the abrasive effect of casein ones $(170 \mu \mathrm{m})$. It is also possible that protection afforded by a diet containing DHA against ACF growth was due to reduced weight gain or reduced caloric intake. Overnutrition and obesity are major determinants of cancer risk (Gerber and Corpet, 1999; WCRF, 2007), and caloric reduction prevents carcinogenesis in 
animals (Kumar et al., 1990; Lutz and Schlatter, 1992). However, the significant ACF reduction observed in rats fed thermolyzed Na-caseinate was not associated with a significant reduction in body weight (Table 1). Therefore, the protection may be due to DHA or other heat-induced compounds. This protection against carcinogenesis might be linked to the induction of protective phase II enzymes by heat-treated protein (Wenzel et al., 2002), or to free radical scavenging properties of $\mathrm{N}$-acyl dehydroalanines that can actually prevent skin tumor promotion (Vo et al., 1991).

The lack of association between dietary LAL and DHA and ACF promotion leaves us without an explanation for the promoting effect of thermolysed casein (Zhang et al., 1992). We have previously speculated that promotion by cooked casein might be due: (i) to extractable products such as heterocyclic amines, (ii) to the reduced digestibility of cooked casein, and the exposure of the epithelium to potentially toxic products of protein fermentation by gut microflora, (iii) to the abrasion of the epithelium by large abrasive particles of thermolyzed casein. These three hypotheses have been tested, but they are not supported by the following previous results: (i) No heterocyclic amine can be detected in solvent extracts from thermolyzed casein, either by highperformance liquid chromatography or by mutagenicity testing, and ACF promotion is not associated with solvent extracts, but with the protein residue (Corpet and Cassand, 1995). (ii) Most thermolyzed casein ingested reaches the colon, but fermentation products like ammonia, phenol, cresol and indole-3-ol are not responsible for the promotion (Corpet et al., 1995). (iii) Thermolyzed casein that has been ground so that particles have a mean diameter of $10 \mu \mathrm{m}$ does not promote colon carcinogenesis (Corpet and Chatelin-Pirot, 1997), suggesting that the abrasion of colon mucosa by large particles of thermolyzed casein $(150 \mu \mathrm{m})$ could promote the growth of colon tumors through increased cell turnover and proliferation (Corpet et al., 1997b). However, a diet containing abrasive carborundum particles of similar diameter does not promote the growth of ACF (Corpet et al., 1997a), which suggest that abrasion alone is not enough to promote carcinogenesis in the colon. Three major hypotheses have thus been tested to explain the strong and consistent promotion of colorectal cancer by thermolysed casein, plus a fourth one here, but none was supported by our experimental studies. We cannot exclude the possibility that heatinduced xenobiotic compounds, not extracted with solvents and different from LAL and DHA, could promote colon carcinogenesis. The data also show that cooked Swiss cheese did not promote colorectal carcinogenesis in rats, as already seen with cooked meat (Parnaud et al., 1998), but in contrast to a model food made of thermolysed pure casein (Table 2). The promotion initially observed with cooked casein thus appears to be a phenomenon associated with thermolysis of the particular isolated, dried casein typically used in animal diets and not the more pliable, soft product consumed as a human food.

\section{Conflict of Interest}

All the authors state they have no conflict of interest in the present study. 
Annex: Proton NMR spectrum assignments are as follows: delta (ppm),

$8.66\left(1 \mathrm{H}, \mathrm{dd}, \mathrm{J}=1.6,6.0 \mathrm{~Hz}, \mathrm{H} 6^{\prime}\right)$;

$8.53\left(1 \mathrm{H}, \mathrm{dt}, \mathrm{J}=1.7,8.0 \mathrm{~Hz}, \mathrm{H} 4^{\prime}\right)$;

$7.99\left(1 \mathrm{H}, \mathrm{dd}, \mathrm{J}=1.0,8.0 \mathrm{~Hz}, \mathrm{H} 3^{\prime}\right)$;

$7.93\left(1 \mathrm{H}, \mathrm{dt}, \mathrm{J}=1.3,6.1 \mathrm{~Hz}, \mathrm{H} 5^{\prime}\right)$;

$4.00(1 \mathrm{H}, \mathrm{dd}, \mathrm{J} 2 \mathrm{a}, 1=4.49 \mathrm{~Hz}, \mathrm{~J} 2 \mathrm{~b}, 1=6.0 \mathrm{~Hz}, \mathrm{H} 1)$;

$3.39(2 \mathrm{H}, \mathrm{t}, \mathrm{J}=7.2 \mathrm{~Hz}, \mathrm{H} 5 \mathrm{a}, \mathrm{H} 5 \mathrm{~b})$;

$3.15(1 \mathrm{H}, \mathrm{dd}, \mathrm{J} 2 \mathrm{a}, 2 \mathrm{~b}=14.66 \mathrm{~Hz}, \mathrm{~J} 2 \mathrm{a}, 1=4.49 \mathrm{~Hz}, \mathrm{H} 2 \mathrm{a})$;

$3.12(1 \mathrm{H}, \mathrm{dd}, \mathrm{J} 2 \mathrm{a}, 2 \mathrm{~b}=14.66 \mathrm{~Hz}, \mathrm{~J} 2 \mathrm{~b}, 1=6.0 \mathrm{~Hz}, \mathrm{H} 2 \mathrm{~b})$;

$3.09(1 \mathrm{H}, \mathrm{dt}, \mathrm{J} 4,5=7.12 \mathrm{~Hz}, \mathrm{H} 4 \mathrm{a})$;

$3.08(1 \mathrm{H}, \mathrm{dt}, \mathrm{j} 4,5=7.12 \mathrm{~Hz}, \mathrm{H} 4 \mathrm{~b})$.

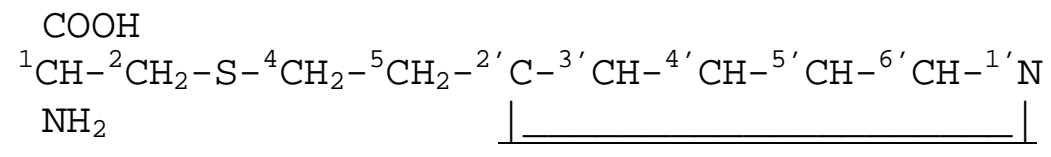

S-beta-(2-pyridylethyl)-cystine structure

\section{Acknowledgements}

We thank Henrianna Pang and Arthur Gray (Department of Medical Genetics, U. of Toronto) for analyses of the NMR and mass spectra; Cecile Canlet (UMR Xénobiotiques, INRA, France) for careful reading of NMR spectra; Jim Ferguson (Ontario Cancer Institute) for help with the reactions with CBZ-DHA; Tiny A. van Boekel (Wageningen, The Netherlands) for the protocol of DHA and pyruvate assay; Raymond Gazel (UMR Xénobiotiques, INRA, France) for good care of the animals; and Ginette Peiffer (Aliment \& Cancer, ENVT, France), for excellent technical assistance. The studies were supported by INRA and ENVT, France, and by The Cancer Research Society, Inc. Montreal, Quebec, Canada. 


\section{References}

American, I. o. N. (1977). Report of the American Institute of Nutrition Ad Hoc Committee on standards for nutritional studies. J Nutr, 107, 1340-1348.

Bachmeier, B. E., Nerlich, A. G., Rohrbach, H., Schleicher, E. D., Friess, U. (2008). Maillard products as biomarkers in cancer. Ann N Y Acad Sci, 1126, 283-287.

Bartone, N. A., Bentley, J. D., Maclaren, J. A. (1991). Determination of dehydroalanine residues in proteins and peptides: An imporved method. J. Protein Chemistry, 10, 603-607.

Bird, R. P. (1987). Observation and quantification of aberrant crypts in murine colon treated with a colon carcinogen: preliminary findings. Cancer Lett, 37, 147-151.

Cattaneo, S., Masotti, F., Pellegrino, L. (2008). Effect of overprocessing on heat damage of UHT milk. Eur Food Res Technol, 226(5), 1099-1106.

Cheftel, J. C., Cuq, J. L., Lorient, D. (1985). Amino acids, peptides, and proteins. in Food Chemistry, OR Fennema ed. Second edit. Marcel Dekker, Inc, NY, 245-369.

Corpet, D. E., Cassand, P. (1995). Lack of aberrant crypt promotion and of mutagenicity in extracts of cooked casein, a colon cancer-promoting food. Nutrition and Cancer, 24(3), 249-256.

Corpet, D. E., Chatelin-Pirot, V. (1997). Cooked casein promotes colon cancer in rats, may be because of mucosal abrasion. Cancer Letters, 114(1-2), 89-90.

Corpet, D. E., Stamp, D., Medline, A., Minkin, S., Archer, M. C., Bruce, W. R. (1990). Promotion of colonic microadenoma growth in mice and rats fed cooked sugar or cooked casein and fat. Cancer Res., 50, 6955-6958.

Corpet, D. E., Tache, S. (2002). Most effective colon cancer chemopreventive agents in rats: a systematic review of aberrant crypt foci and tumor data, ranked by potency. Nutrition and Cancer, 43(1), 1-21.

Corpet, D. E., Tache, S., Peiffer, G. (1997a). Carborundum, a bulk similar to dietary fibers but chemically inert, does not decrease colon carcinogenesis. Cancer Letters, 114(1-2), 35-38.

Corpet, D. E., Tache, S., Peiffer, G. (1997b). Colon tumor promotion: is it a selection process? effects of cholate, phytate, and food restriction in rats on proliferation and apoptosis in normal and aberrant crypts. Cancer Letters, 114(1-2), 135-138.

Corpet, D. E., Yin, Y., Zhang, X. M., Remesy, C., Stamp, D., Medline, A., Thompson, L., Bruce, W. R., Archer, M. C. (1995). Colonic protein fermentation and promotion of colon carcinogenesis by thermolyzed casein.

Nutrition and Cancer - an International Journal, 23(3), 271-281.

D'Agostina, A., Boschin, G., Rinaldi, A., Arnoldi, A. (2003). Updating on the lysinoalanine content of commercial infant formulae and beicost products. Food Chemistry, 80(4), 483-488.

De Groot, A. P., Slump, P., Feron, V. J., Van Beek, L. (1976). Effects of alkali treated proteins : feeding studies with free and protein bound lysinoalanine in rats and other animals. J Nutr, 106, 1527-1538.

Deng, Q. Y., Barefood, R. R., Diosad, L. L., Rubin, L. J., Tzeng, Y. M. (1990). Lysinoalanine concentrations in rapeseed protein meals and isolates. Can. Inst. Food Sci. Technol. J., 23, 140-142.

Finley, J. W., Friedman, M. (1977). New amino acid derivatives formed by alkaline treatment of proteins.

. Adv Exp Med Biol, 86B, 123-130.

Friedman, M. (1999). Chemistry, biochemistry, nutrition, and microbiology of lysinoalanine, lanthionine, and histidinoalanine in food and other proteins. Journal of Agricultural and Food Chemistry, 47(4), 1295-1319.

Gerber, M., Corpet, D. (1999). Energy balance and cancers. Eur J Cancer Prev, 8(2), 77-89.

Kleyn, D. H., Klostermeyer, H. (1980). Dehydroalanin als Reaktionsproduct bei der Erhitzung von B-casein. Z. Lebensm. Unters. Forsch., 170, 11-13.

Kumar, S. P., Roy, S. J., Tokumo, K., Reddy, B. S. (1990). Effect of different levels of caloric restriction on azoxymethane induced colon carcinogenesis in male F344 rats. Cancer Research, 50, 5761-5766.

Lutz, W. K., Schlatter, J. (1992). Chemical carcinogens and overnutrition in diet-related cancer. Carcinogenesis, 13(12), 2211-2216.

Maga, J. A. (1984). Lysinoalanine in foods. J Agric Food Chem, 32:955-964.

Masri, M. S., Friedman, M. (1982). Transformation of dehydroalanine residues in casein to S-beta-(2-

pyridylethyl)-L-cysteine side chains. Biochem Biophys Res Commun, 104(1), 321-325.

Millipore-corporation (1984). PICO. TAG Work Station Operator's Manual. Millipore corporation, Milford, MA.

Parnaud, G., Peiffer, G., Tache, S., Corpet, D. E. (1998). Effect of meat (beef, chicken, and bacon) on rat colon carcinogenesis. Nutrition and Cancer, 32(3), 165-173.

Pintauro, S. J., Philippossian, G., Finot, P. A., Lee, T. C. (1985). Lysinoalanine: absence of mutagenic response in the Salmonella/mammalian-microsome mutagenicity assay. Food Chem Toxicol, 23(8), 763-765.

Sternberg, M., Kim, C. Y., Schwende, F. J. (1975). Lysinoalanine: presence in foods and food ingredients.

Science, 190(4218), 992-994. 
Struthers, B. J., Dahlgren, R. R., Hopkins, D. T. (1977). Biological effects of feeding graded levels of alkali treated soybean protein containing lysinoalanine in Sprague-Dawley and Wistar rats. J Nutr, 107, 1190-1199. Sugimura, T., Wakabayashi, K., Nakagama, H., Nagao, M. (2004). Heterocyclic amines: Mutagens/carcinogens produced during cooking of meat and fish. Cancer Sci, 95(4), 290-299.

Vlassara, H., Uribarri, J., Cai, W., Striker, G. (2008). Advanced glycation end product homeostasis: exogenous oxidants and innate defenses. Ann N Y Acad Sci, 1126, 46-52.

Vo, T. K., Fischer, S. M., Slaga, T. J. (1991). Effects of N-acyl dehydroalanines on phorbol ester-elicited tumor development and other events in mouse skin. Cancer Lett, 60(1), 25-32.

WCRF, W. C. R. F. (2007). Food, nutrition, physical activity, and the prevention of cancer: a global perspective. WCRF and American Institute for Cancer Research, Washington DC, 1-537.

Wenzel, E., Tasto, S., Erbersdobler, H. F., Faist, V. (2002). Effect of heat-treated proteins on selected parameters of the biotransformation system in the rat. Annals of Nutrition and Metabolism, 46(1), 9-16.

Zhang, X. M., Stamp, D., Minkin, S., Medline, A., Corpet, D. E., Bruce, W. R., Archer, M. C. (1992). Promotion of aberrant crypt foci and cancer in rat colon by thermolyzed protein. Journal of the National Cancer Institute, 84(13), 1026-1030. 
Table 1. Aberrant Crypt Foci (ACF) in the colon of rats fed thermolysed protein for 100 days after initiation by azoxymethane, and dehydroalanine (DHA) level in proteins and feces.

\begin{tabular}{|c|c|c|c|c|c|c|c|}
\hline $\begin{array}{c}\text { Protein } \\
+ \text { abrasive }^{\mathrm{a}}\end{array}$ & $\begin{array}{l}\text { Heat } \\
\text { treat- } \\
\text { ment }\end{array}$ & $\begin{array}{l}\text { Final body } \\
\text { weight }(\mathrm{g})\end{array}$ & $\begin{array}{c}\mathrm{ACF} \\
\text { /Colon }\end{array}$ & Crypts/ACF & $\begin{array}{l}\text { Tumors } \\
/ 10 \text { rats }\end{array}$ & $\begin{array}{l}\text { DHA in } \\
\text { protein } \\
(\mathrm{ppm})\end{array}$ & $\begin{array}{c}\text { DHA in } \\
\text { dried } \\
\text { feces } \\
(\mathrm{ppm})\end{array}$ \\
\hline Casein & None & $165 \pm 11^{b}$ & $114 \pm 22$ & $2.49 \pm 0.32$ & 0 & $<$ d.1. ${ }^{\mathrm{g}}$ & $<\mathrm{d} .1$. \\
\hline Casein & $\begin{array}{c}\text { Thermo } \\
\text {-lyzed }\end{array}$ & $157 \pm 13$ & $101 \pm 53$ & $3.34 \pm 0.21^{\mathrm{e}}$ & $6^{f}$ & 5050 & 2350 \\
\hline Na-caseinate & None & $163 \pm 11$ & $102 \pm 43$ & $2.54 \pm 0.23$ & 0 & $<\mathrm{d} .1$. & $<\mathrm{d} .1$ \\
\hline Na-caseinate & $\begin{array}{l}\text { Thermo } \\
\text {-lyzed }\end{array}$ & $154 \pm 14$ & $44 \pm 24^{\mathrm{d}}$ & $1.88 \pm 0.23^{\mathrm{e}}$ & 0 & 5670 & 1540 \\
\hline $\begin{array}{l}\text { Na-caseinate } \\
+ \text { carborundum }\end{array}$ & None & $162 \pm 13$ & $125 \pm 40$ & $2.75 \pm 0.27$ & 0 & $<\mathrm{d} .1$. & $<\mathrm{d} .1$ \\
\hline $\begin{array}{l}\text { Na-caseinate } \\
+ \text { carborundum }\end{array}$ & $\begin{array}{c}\text { Thermo } \\
\text {-lyzed }\end{array}$ & $149 \pm 13^{c}$ & $41 \pm 20^{e}$ & $1.74 \pm 0.18^{\mathrm{e}}$ & 0 & 5670 & 1450 \\
\hline
\end{tabular}

${ }^{\mathrm{a}}$ See diet composition in the Material and Methods section.

${ }^{\mathrm{b}}$ Values are mean $\pm \mathrm{SD}$ from 10 rats. Starting body weights were similar in each group (125$127 \mathrm{~g} / \mathrm{rat})$.

c,d,e Significantly different from corresponding raw control diet by Student's t-test $\left({ }^{\mathrm{C}} \mathrm{P}=0.04,{ }^{\mathrm{d}}\right.$ $\left.\mathbf{P}<0.002,{ }^{\mathrm{e}} \mathbf{P}<0.0001\right)$

${ }^{\mathrm{f}}$ Significantly different from raw casein control diet by Fisher's exact test $(\mathrm{P}=0.03)$

${ }^{\mathrm{g}}$ Below the detection limit of the method. 
Table 2. Aberrant Crypt Foci (ACF) in the colon of rats fed Swiss cheese, uncooked or cooked for $1 \mathrm{~h} 30$ at $200^{\circ} \mathrm{C}$, for 100 days after initiation by azoxymethane, and dehydroalanine (DHA) level in cheese and in feces.

\begin{tabular}{|c|c|c|c|c|c|c|}
\hline Diet $^{\text {a }}$ & $\begin{array}{c}\text { Final body } \\
\text { weight (g) }\end{array}$ & $\begin{array}{c}\text { ACF } \\
\text { /Colon }\end{array}$ & $\begin{array}{c}\text { Crypts } \\
\text { /ACF }\end{array}$ & $\begin{array}{c}\text { Large ACF } \\
\text { (>5 Crypts) }\end{array}$ & $\begin{array}{c}\text { DHA in } \\
\text { protein } \\
\text { (ppm) }\end{array}$ & $\begin{array}{c}\text { DHA in dried } \\
\text { feces (ppm) }\end{array}$ \\
\hline $\begin{array}{c}\text { Raw } \\
\text { cheese }\end{array}$ & $194 \pm 9^{\mathrm{b}}$ & $169 \pm 31$ & $2.11 \pm 0.12$ & $22.5 \pm 5.6$ & $<$ d.1. ${ }^{\mathrm{d}}$ & $<\mathrm{d} .1$. \\
\hline $\begin{array}{c}\text { Cooked } \\
\text { cheese }\end{array}$ & $164 \pm 8^{\mathrm{c}}$ & $153 \pm 46$ & $1.61 \pm 0.16^{\mathrm{c}}$ & $6.2 \pm 5.7^{\mathrm{c}}$ & $3050 \pm 210$ & $1470 \pm 150$ \\
\hline
\end{tabular}

${ }^{\mathrm{a}}$ See diet composition in the Material and Methods section.

${ }^{\mathrm{b}}$ Starting body weight was $106 \mathrm{~g}$ per rat in both groups. Values are mean $\pm \mathrm{SD}$ from 10 rats

${ }^{\mathrm{c}, \mathrm{d}}$ Significantly different from raw cheese control diet by Student's t-test $\left({ }^{\mathrm{c}} \mathrm{P}<0.0001,{ }^{\mathrm{d}} \mathrm{P}=0.024\right)$.

${ }^{d}$ Below the detection limit of the method. 
Figure legend

Fig. 1. (A) Concentration of lysinoalanine, in casein, plotted as a function of the duration of the thermolysis $\left(180^{\circ} \mathrm{C}\right)$ of casein. The data are typical assay of three replicates.

(B) Concentration of dehydroalanine, in casein, plotted as a function of the duration of the thermolysis $\left(180^{\circ} \mathrm{C}\right)$ of casein. The data are typical assay of three replicates.

(C) Percentage increase in aberrant crypt focus size, measured as the number of crypts /ACF at $100 \mathrm{~d}$ plotted as a function of the duration of the thermolysis $\left(180^{\circ} \mathrm{C}\right)$ of casein in the diet. Error bars are 95\% Confidence Intervals. Original ACF data have already been published (Corpet et al., 1995). 

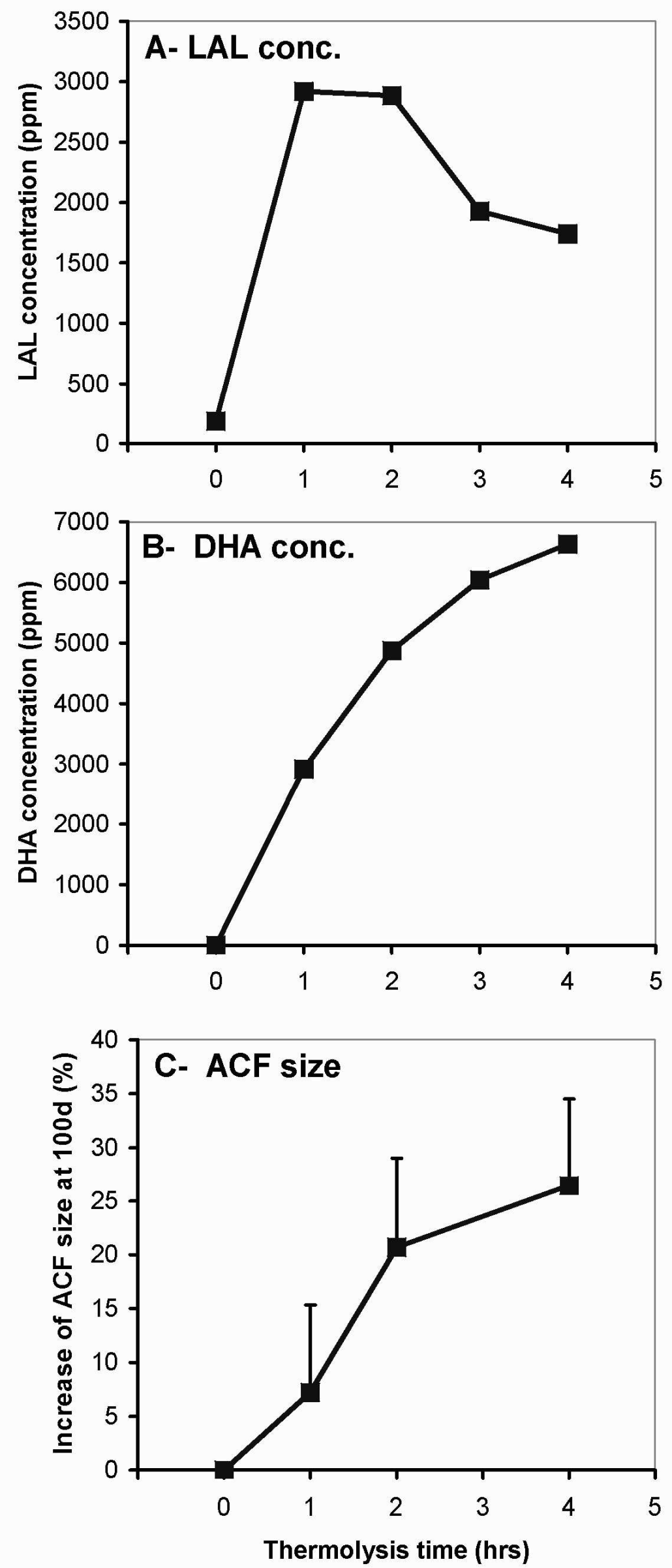